of California School of Medicine, San Francisco) discussion of DNA repair enzymes.

From a string of beads, visible under the electron microscope, to a chromosome as seen under the light microscope, needs a great leap of the imagination. $\mathrm{H1}$, which has a hydrophobic globular core and the very basic amino, as well as carboxyl, terminus is a good candidate for maintaining higher order helical packing of the string of beads by bridging nucleosomes at a certain interval. According to D. Cole (University of California, Berkeley) H5 (found in vertebrates with nucleated erythrocytes) as well as some of the so-called HMG proteins of I. Isenberg, can be considered as allies of $\mathrm{H} 1$. Furthermore, he has shown that each mammalian species generates not one, but several organ-specific species of $\mathrm{Hl}$. Data from sea urchin indicates that the basic histone genetic unit contains one each of the $\mathrm{H} 1, \mathrm{H} 2 \mathrm{~A}, \mathrm{H} 2 \mathrm{~B}$, $\mathrm{H} 3$ and $\mathrm{H} 4$ genes. Cole's findings and the similar finding by Isenberg (Oregon State University) for $\mathrm{H} 2 \mathrm{~A}$ indicates that the genome of higher vertebrates contains not one but several genetic units for histones that are the same with regard to the $\mathrm{H} 4$ gene but different with regard to $\mathrm{H} 1$ genes and to a lesser extent $\mathrm{H} 2 \mathrm{~A}$ genes. In this connection, an apparent paradox is noted with great interest. Using $\mathrm{H} 4$ message purified from $\mathrm{HeLa}$ cells, W. Prensky (Tufts University, Boston) reported that the number of histone gene copies in the human genome is only of the order of tens rather than hundreds and is localised on the short arm of chromosome 7 near its centromere. By contrast not only with sea urchins and frogs but also with the cat, the human genome apparently contains fewer copies of each of the multigene families. This is true for the 5S RNA genes (found on the long arm of chromosome 1) and also of the $18 \mathrm{~S}$ and $28 \mathrm{~S}$ RNA genes (distributed among five pairs of acrocentricschromosomes 15, 16, 17, 21 and 22).

I wonder if humans owe their extraordinary longevity to the fact that they possess so few copies of these genes. It seems to me that having too many copies of a functionally ubiquitous gene is a curse rather than a blessing to somatic cells. Mutations which alter function (suppressor-type mutations of RNA genes, for example) sustained by a few copies out of hundreds or thousands are not likely to be particularly deleterious, and so may accumulate, resulting in more and more mistranslations and mistranscriptions leading finally to the general deterioration so characteristic of the ageing process. With fewer gene copies, mutated cells will be eliminated more efficiency thus delaying ageing.

\title{
Of winged beans and Wom Poms
}

\author{
from Robert M. May
}

ADMIRERs of Michael Flanders and Donald Swann will recall their hymn to the fabulous Wom Pom plant (Angel Record 35797): "You can do such a lot with a Wom Pom / You can use every part of it too... The flesh in the heart of a Wom Pom / Has the flavour of porterhouse steak / And the juice is a liquor / That will get you higher quicker . . Gaudeamus Wom Pom, gladly we salute / Vade mecum Wom Pom, philanthropic fruit."

Nature's closest approximation to the Wom Pom may well be the littleknown tropical legume, Psophocarpus tetragonolobus or winged bean. In its study of underexploited tropical plants with promising economic value (see Nature 265, 209; 1977), a panel of the US National Academy of Sciences under the direction of Noel Vietmeyer decided that the exceptional merits of the winged bean deserved a separate and deeper examination. The fruits of that work are set out in The Winged Bean: A High-Protein Crop for the Tropics (NAS, Washington DC, 1975).

Today the winged bean is grown only as a backyard crop in Papua New Guinea and Southeast Asia. These regions are, however, typical of the humid tropical zone that includes large parts of Central and South America, the Caribbean, Africa, Oceania, and West Asia, where protein deficiency is high and the plant is still unknown; not many edible crops with such high protein content will grow in these regions. Unlike the soybean (where only the seeds are used), all parts of the winged bean can be eaten: tubers, seeds, leaves, flowers, and shoots.

The immature pods are highly palatable, and can be eaten raw. The seeds are similar in composition to soybeans, averaging $34 \%$ protein (by dry weight) and $17 \%$ oil. The seeds give an edible oil, with a good proportion of polyunsaturated essential fatty tropics.

How a chromosome or rather a chromatid manages to pack $10^{8}$ or more DNA base pairs into itself is a mystery still unresolved. After listening to discussions of sister chromatid exchanges by $S$. Latt (Children's Hospital Medical Center, Boston) and S. Wolff (University of California Medical Center) and of meiotic segregation by $M$. Moses (Duke University School of Medicine), one cannot help but marvel at the ease with which two sister DNA strands manage to sort themselves out without too much unwinding. All the tortuous models proposed so far are likely to be well off target. To discuss the mechanism of $Q$ acids. The tuberous roots are slightly sweet, and contain 20\% protein (by dry weight). This is spectacularly higher than the protein content in other edible roots and tubers such as cassava $(1 \%)$, potatoes $(2 \%)$, sweet potatoes $(2 \%)$, or yams $(2 \%)$.

Like other leguminous plants, the winged bean fixes atmospheric nitrogen by bacteria in nodules on the roots. Compared with other edible legumes, $P$. tetragonolobus appears to have more and larger nodules on its extensive root system, which may account for the plant's exceptional protein content. These factors are also probably responsible for the plant's ability to grow well in tropical soils poor in nitrogen, and in newly cleared soils (without the inoculation with appropriate soil bacteria demanded by many other tropical legumes). It can also be used in crop rotations to restore soil nitrogen.

Little is known about the varieties of $P$. tetragonolobus. Those currently cultivated require staking to produce high yields of pods and seeds. The NAS report acknowledges that this method of agriculture is impractical and uneconomical for mass cropping, and that not all winged bean pods mature at the same time, so that the plant is not likely to rival the soybean as a large-scale commercial product in the near future. "Its potential is as a subsistance crop or as a cash crop for small markets. For these purposes, the fact that it produces food during many months is an advantage, and staking is not a serious handicap".

One of the long term benefits that may well come from research on in vitro recombinant DNA is better crops, genetically engineered to our requirements. In the short run, however, we could make better use of what nature has provided, particularly in the

and G-banding and of R-banding without knowing the packing method the chromosome uses is likely to be futile. Although D. Comings (City of Hope Medical Center) pointed out that a $5 \%$ difference in GC/AT ratio may make a $50 \%$ difference in fluorescence intensity, the fact that anti-single base antibodies (O. J. Miller) as well as G-C specific antibodies (J. H. Van de Sande), can also band chromosomes, seems to indicate that what matters is not the base composition of a whole long stretch but short stretches here and there that occupy exposed or accessible positions on the chromosome. I have amused myself with the 